
www.globaljournalseries.com, Email: info@globaljournalseries.com

\title{
EFFECTIVENESS OF THE AJAYI - MAKINDE TWO - ELECTRODE ARRAY AS A GEOELECTRIC PROSPECTING METHOD IN DEPTH - TO - BASEMENT DETERMINATION
}

DAVID BACHAMA YUSUF AND MARIUS N. UMEGO

(Received 10 February 2014; Revision Accepted 15 May 2014)

\begin{abstract}
A geoelectric investigation employing vertical electrical soundings (VES) using the Ajayi - Makinde Two-Electrode array and the conventional Schlumberger configuration was carried out in the Main Campus of Ahmadu Bello University (A.B.U.) Zaria with the aim of testing the reliability and effectiveness of the Ajayi-Makinde Two - Electrode array in depth - to - basement determinations. Interpretations of the two-electrode data and the Schlumberger data revealed that the geometry of the bedrock underlying the Main Campus is undulating. The depth - to - basement values for the Ajayi - Makinde Two - Electrode array ranges from $13.0 \mathrm{~m}$ in the central part of the study area to about $30.0 \mathrm{~m}$ around the southern end while that obtained from the Schlumberger configuration ranges from $11.0 \mathrm{~m}$ in the central part of the study area to about $29.0 \mathrm{~m}$ in the southern end. Results of the VES interpretation obtained in this work using the Ajayi - Makinde Two - Electrode array have compared very well with those obtained using the Schlumberger array at the same VES stations. The depth - to - basement values obtained in this work have also compared well with those obtained by previous researchers in the area. The Ajayi - Makinde Two - Electrode array is therefore reliable and effective and can be of use as a geoelectric prospecting method.
\end{abstract}

KEYWORDS: Two-Electrode Array, Vertical Electrical Sounding, Depth-to-Basement and "Bulk Resistivity"

\section{INTRODUCTION}

There are quite a number of different electrode arrangements used in electrical D.C. resistivity survey. These include the two - electrode arrangement, the three - electrode arrangement, the common four electrode arrangement and the six - electrode arrangement (Jain and Roy, 1973).

The four - electrode arrangement is actually the most widely used electrode arrangement for electrical resistivity surveys. Of the different forms of the four electrode arrays, the Wenner and Schlumberger Configurations are the most commonly used arrangements. Jain and Roy (1973) have discussed the theory of these arrangements, both of which employ four electrodes arranged along straight lines

Apparao and Roy (1973) and Kumar (1974), worked on a combination which consists of one current electrode and one potential electrode placed at sufficiently large distance that can approximate to infinity from the measuring environment. Gupta and Bhattacharya (1963) and Brizzolari and Bernabini (1979), reported on a combination that consists of two current electrodes both of which feed current into the ground with non acting as a return electrode.

The two - electrode method used in this work is that used by Makinde in 1996. The configuration is now referred to as the Ajayi - Makinde Two - electrode array (Ajayi and Makinde, 2000). The theory and arrangement of the method also referred to as the $\mathrm{C}-\mathrm{C}$ mode is given in Ajayi and Makinde (2000)

\section{AIM AND OBJECTIVES}

The primary aim of this work is to test the reliability and effectiveness of the Ajayi - Makinde two electrode method in depth - to - basement determinations. This aim will be achieved by:

$>$ Carrying out vertical electrical D.C. resistivity surveys using the Ajayi - Makinde Two - electrode array and then followed by the Schlumberger array at the same VES stations.

$>$ Comparing the results obtained from the VES interpretations of both sets of data and also with the results obtained by previous workers in the area.

The Main Campus of A.B.U. Zaria situated in the Kubanni River Basin was chosen as the project area in this work because the geology of the basin is well known.

\section{LOCATION AND GEOLOGY OF THE STUDY AREA}

The Main Campus of Ahmadu Bello University (A.B.U.) Zaria is the project area investigated in this work. It is part of the Kubanni River Basin which is situated in the north-central part of Nigeria (Fig. 1).

The Main Campus is located in the north western part of the Kubanni Basin and occupies about $9 \%$ of the area of the basin. The Main Campus is approximately bounded by latitudes $11^{\circ} 09^{\prime} \mathrm{N}$ and $11^{\circ}$ $10^{\prime} \mathrm{N}$ and longitudes $7^{0} 38^{\prime} \mathrm{E}$ and $7^{0} 39^{\prime} \mathrm{E}$ (Fig.1). It is a built up area and the part investigated in this work is the western half of the Main Campus.

As reported by McCurry (1970), the Nigerian

David Bachama Yusuf, Physics Unit, S.B.R.S., Gombe State University, Gombe State, Nigeria.

Marius N. Umego, Department of Physics and Industrial Physics, Nnamdi Azikiwe University, Awka, Nigeria 
basement complex rocks are exposed over more than half of the land surface of Nigeria. The rocks are exposed mostly in the northern, western and eastern flank of Nigeria that has border with the Republic of Cameroun.
According to Thorp (1970), Zaria, which contains the Main Campus of A.B.U. Zaria, is a part of the gently undulating peneplain that extends east -west from Lake Chad to Sokoto and northwards from the southern parts of Kaduna to Tripoli in the Republic of Niger.

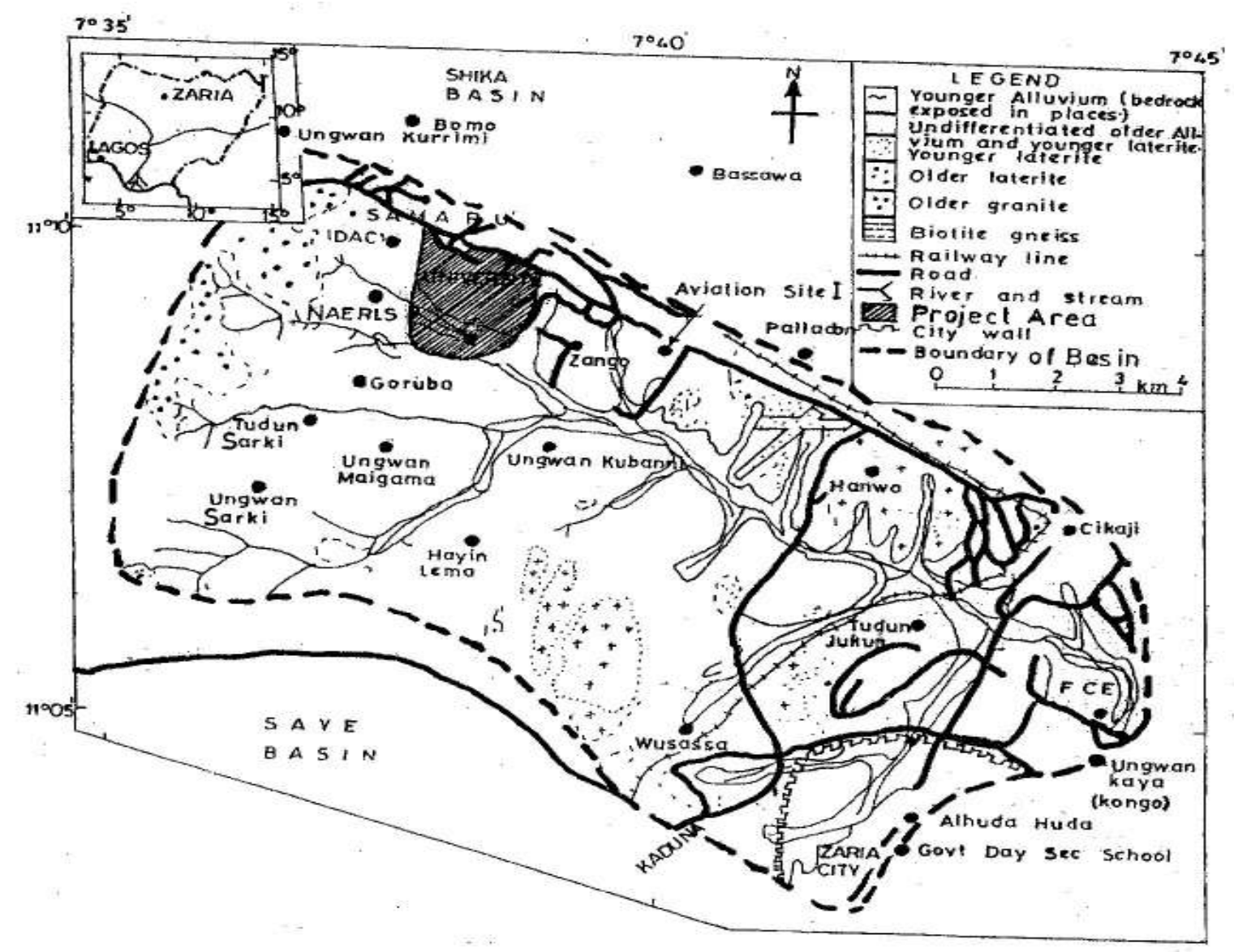

Fig. 1: Location of the Project Area within the Geological Map of the Kubanni Basin(Modified from Shemang, 1990).

As stated by Oyawoye (1964), the Nigerian basement complex is the end result of at least two major cycles. The last of the cycles probably extended from Late Cambrian to Lower Paleozoic. The cycles were believed to have been be initiated by the deposition of thick sands, mud and greywacke on igneous material cover and eroded metamorphic basement during the preceding cycle Oyawoye (1964).

As a result of the extensive re- metamorphism and partial mobilization of the underlying basement, the accumulated materials were developed into high-grade gneiss, migmatites and older granite (Trustwell and Cope, 1963; Wright and McCurry, 1970). The superficial deposits that cover most of the basement rocks in the
Kubanni Basin act as recharge areas where they are underlain by weathered basement (Eigbefo, 1978).

The Main Campus is underlain by Precambrian rocks of the Nigerian basement complex. Muscovite biotite-gneiss occupies the southern and western parts of the Campus while the northern and eastern parts are underlain by biotite granite-gneiss (Eigbefo, 1978).

The laterite contains little water which is mostly unconsolidated and, because they are shallow, they receive direct recharge from rainfall. The alluvial deposit in Zaria area consists of gravels, sands, silts and clay which are mostly found along stream channels.

According to Olowu (1967) and Eigbefo (1978), the weathered basement is the main storage element for groundwater in the Kubanni basin. As the case in the 
entire basin, the aquifer in the Main Campus is covered by laterite loam (Wright and McCurry, 1970; Eigbefo, 1978). Their thickness ranges from 5 - $15 \mathrm{~m}$ (Olowu, 1967).

A lot of geophysical studies have been carried out in the Kubanni Basin. Most of the researchers such as: Ososami (1968), Olugbemiro (1985), Hassan (1987), Shemang (1990), Bajeh (1992), Makinde (1996), Afolalu (2009),

Ameloko and Rotimi (2010), Ameloko and Omali (2011), Egwuonwu and Sule (2012), Fadele et al (2013), Osumeje and Kudamnya (2014) reported that the bedrock in the Kubanni Basin is undulating with depth values ranging from less than a metre to a maximum of about $50 \mathrm{~m}$.

\section{DATA ACQUISITION, REDUCTION AND INTERPRETATION}

The fieldwork in this research was carried out in the month of March, during the dry season. A total of thirtyseven (37) points were sounded. The points "sounded" or "stations established" were carefully selected to ensure adequate and uniform coverage of the study area as shown in Fig. 2.

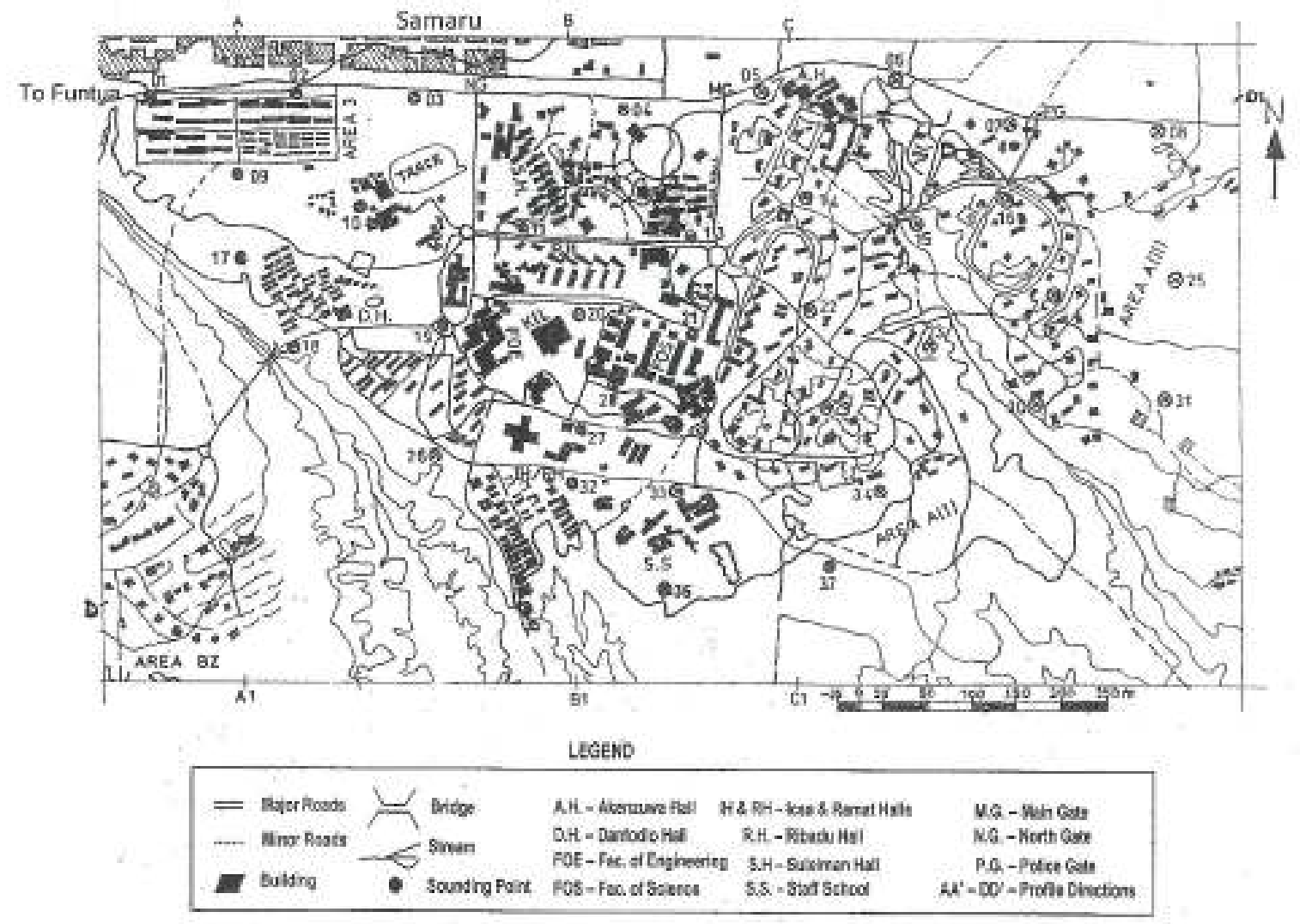

Fig. 2: Map of the Study Area Showing the Sounding Points (Courtesy Of U.R.P. Dept. ABU, Zaria)

Vertical electrical sounding (VES) were carried out at each of the 37 stations using the two - electrode array and then followed by the Schlumberger configuration. Thus a total of seventy- four (74) VES were conducted.

As the Ajayi - Makinde Two - electrode array is a new technique, no equipment had, as at the time of the fieldwork, been fabricated for it. Hence an arrangement which basically consist of an electric generator as the power source, a voltmeter, an ammeter, two copper electrodes, two reels of wire and connecting wires were used. The electric generator is an ET 500 YAMAHA with an output of $250 \mathrm{~V}, 50 \mathrm{~Hz}$, capable of delivering a maximum current of $300 \mathrm{~mA}$. A high tension laboratory power pack was used to convert the alternating current (A.C.) to direct current (D.C.), which was then passed into the ground through the copper electrodes. A voltmeter with a range of $0-300 \mathrm{~V}$ was used to measure the potential difference $(V)$ across the electrodes while an ammeter with a range of $0-300$ $\mathrm{mA}$ measures the current (I) passed into the ground.

The field equipment used for the Schlumberger configuration consists of an ABEM Terrameter SAS 300, copper electrodes, four reels of wire and connecting wires.

For the two - electrode array, the field procedure involved the expansion of $L / 2$ (half the current electrode spacing) symmetrically about the centre point or point being sounded. Half the current electrode spacing $L / 2$ was expanded in steps from $0.5 \mathrm{~m}$ to a maximum of 100 $\mathrm{m}$. For each measurement, I, V and the electrode spacing $L$ were recorded. 
Table 1: Typical Reduced Data Using the Two-Electrode Array for VES 25.

\begin{tabular}{|c|c|c|c|c|}
\hline $\mathbf{L}(\mathbf{m})$ & $\mathbf{L} / \mathbf{2}(\mathbf{m})$ & $\begin{array}{l}\mathbf{V} \\
(\mathbf{V o l t s})\end{array}$ & $\mathbf{I}(\mathbf{m A})$ & $\boldsymbol{\rho}_{\mathbf{b}}(\mathbf{\Omega} \mathbf{~ m})$ \\
\hline 1.0 & 0.50 & 188 & 42 & 659.2 \\
\hline 2.0 & 1.00 & 174 & 32 & 1601.5 \\
\hline 3.0 & 1.50 & 147 & 54 & 202.6 \\
\hline 4.0 & 2.00 & 173 & 34 & 997.2 \\
\hline 5.0 & 2.50 & 135 & 45 & 208.9 \\
\hline 6.0 & 3.00 & 120 & 48 & 208.9 \\
\hline 7.0 & 3.50 & 113 & 46 & 713.2 \\
\hline 8.0 & 4.00 & 106 & 39 & 202.0 \\
\hline 9.0 & 4.50 & 91 & 43 & 804.8 \\
\hline 10.0 & 5.00 & 120 & 55 & 212.9 \\
\hline 15.0 & 7.50 & 101 & 52 & 290.4 \\
\hline 20.0 & 10.00 & 122 & 49 & 333.1 \\
\hline 25.0 & 12.50 & 116 & 51 & 373.7 \\
\hline 30.0 & 15.00 & 105 & 56 & 283.5 \\
\hline 35.0 & 17.50 & 103 & 53 & 0016.6 \\
\hline 40.0 & 20.00 & 72 & 44 & 9638.9 \\
\hline 45.0 & 22.50 & 75 & 45 & 1044.7 \\
\hline
\end{tabular}

Table 2: Typical Reduced Data Using the Schlumberger Array for VES 25.

\begin{tabular}{|c|c|l|l|}
\hline $\mathbf{M N}(\mathbf{m})$ & $\mathbf{A B} / \mathbf{2}(\mathbf{m})$ & $\mathbf{R}(\boldsymbol{\Omega})$ & $\boldsymbol{\rho}_{\mathbf{b}}(\boldsymbol{\Omega} \mathbf{~})$ \\
\hline 1.0 & 1.00 & 193.0240 & 454.8 \\
\hline & 1.50 & 68.4525 & 430.1 \\
\hline & 2.50 & 22.5050 & 424.2 \\
\hline & 3.75 & 8.5013 & 368.9 \\
\hline & 5.00 & 4.1271 & 320.9 \\
\hline & 7.50 & 1.1890 & 209.2 \\
\hline & 10.00 & 0.6111 & 191.5 \\
\hline 3.0 & 7.50 & 3.9470 & 223.2 \\
\hline & 10.00 & 1.6270 & 166.5 \\
\hline & 15.00 & 0.5179 & 120.8 \\
\hline & 25.00 & 0.1852 & 120.8 \\
\hline & 37.50 & 0.1131 & 166.5 \\
\hline & 50.00 & 0.0721 & 188.8 \\
\hline 10.0 & 37.50 & 0.3890 & 168.9 \\
\hline & 50.00 & 0.2830 & 220.1 \\
\hline & 75.00 & 0.1677 & 295.1 \\
\hline & 100.00 & 0.1194 & 374.1 \\
\hline
\end{tabular}

In deriving the formula for calculating the apparent or "bulk" resistivity, $\rho_{b}$. Ajayi and Makinde (2000), assumed that: the portion of the earth material sounded by the electrodes is a hemisphere whose volume can be approximated by a horizontal cylinder of the same volume but whose diameter is $L / 2$.
Applying the simple expression of Ohm's law (i.e. $R=\frac{V}{I}$ ) and by extension to the Ajayi - Makinde two- electrode sounding analog for a cylindrical load of uniform cross-section $A$ and length $l$, the resistivity of the load is 


$$
\rho=\frac{R A}{l}
$$

Substituting for $R=\frac{V}{I}$ into equation (1) gives

$$
\rho=\frac{A}{l} \frac{V}{I}
$$

The volume of a sphere of radius $r$ is $(4 / 3) \pi r^{3}$, hence, the volume $v$, of the equivalent hemisphere is $(2 / 3) \pi r^{3}$.

But $r=L / 2$

$$
\text { Hence, } \begin{aligned}
v & =\frac{2 \pi(L / 2)^{3}}{3} . \\
v & =\frac{\pi L^{3}}{12} \ldots \ldots \ldots . .
\end{aligned}
$$

The volume, v, in equation (4) is also the volume of the equivalent cylinder of the load, i.e.,

$$
\pi\left(\frac{L}{4}\right)^{2} l=\frac{\pi L^{3}}{12}
$$

Where $l$ is the length of the cylinder. This implies that

$$
l=\frac{4 L}{3} \text {. }
$$

The cross-sectional area, $A$, of the cylinder is

$$
A=\pi x^{2}=\pi\left(\frac{L}{4}\right)^{2}
$$

where $X=\frac{L}{4}=$ radius of cylinder.

$$
\text { Thus } \quad A=\frac{\pi L^{2}}{16} \ldots \ldots \ldots \ldots \ldots .
$$

Substituting for equations (6) and (7) into (3) gives

$$
\begin{aligned}
& p-\left(\frac{3 \pi}{32}\right)\left(\frac{L}{2}\right)\left(\frac{V}{I}\right) \ldots \ldots \ldots \\
& \rho=\frac{3 \pi}{64} L\left(\frac{V}{I}\right) \\
& \text { or } \rho=k \frac{V}{I}
\end{aligned}
$$

where $k=(3 \pi \mathrm{L}) / 64$ is the geometric factor of the array. Since the various layers being sampled as the electrode spacing increases are not of the same material, $\rho$ in equation (10) is actually the "bulk" or apparent resistivity $\rho_{b}$ of the layers sounded. Hence equation (10) is better written as

$$
\rho_{b}=k \frac{V}{I} \ldots \ldots \ldots \ldots \ldots \ldots \ldots
$$

From equation (11) a plot of $\rho_{b}$ against L/2 is expected to give a set of straight lines whose slope is given by

$$
S_{n}= \pm \frac{3 \pi}{32}\left(\frac{V}{I}\right)
$$

Keller and Frischknecht (1966) assumed that the resistivity of the earth $\rho_{z}$ at depth $z$, is given by

$$
\rho_{z}=\rho_{1} e^{ \pm \alpha z}
$$

where $\rho_{z}$ is the resistivity at depth $z, \rho_{1}$ is the resistivity at the surface or top and $\alpha$ is a parameter defining the rate of increase or decrease with depth.

Taking the logarithm of both sides of equation (13) gives

$$
\ln \rho_{z}=\ln \rho_{1} \pm \alpha z
$$

It therefore follows that a plot of $\ln \rho_{z}$ against $z$ is expected to give a straight line whose slope is $\alpha$ and intercept $l n \rho_{1}$. The computed "bulk" resistivity $\rho_{b}$, values as in Table 1 were determined by equation (11). The values of $\rho_{h}$ and their corresponding values of $L / 2$ plotted on a semi-log graph sheet is expected according to equation (13) to give a series of straight lines joined end-to-end. The intercepts on the $L / 2$ axis at the points of intersection of the straight line segments gives the depth of the various layers. Fig. 3 is a typical example of such a plot for VES station 25.

As adopted by Makinde (1996), the intercept (i.e. h) values of the points of intersection of the segments of a plot on the horizontal (L/2) axis were read off. The intercept $\left(h_{1}\right)$ of the first two segments gives the thickness of the first layer while the intercept $\left(h_{2}\right)$ of the $2^{\text {nd }}$ and $3^{\text {rd }}$ segments gives the depth of the $2^{\text {nd }}$ layer from the surface. The thickness of the $2^{\text {nd }}$ layer is therefore $\left(h_{2}-h_{1}\right)$. The depth - to -basement value $(H)$ is the value of the intercept of the last two segments of a plot. For VES station 25 (Fig. 3) the depth to the basement is $\mathrm{H}=\mathrm{h}_{2}=23.4 \mathrm{~m}$. 


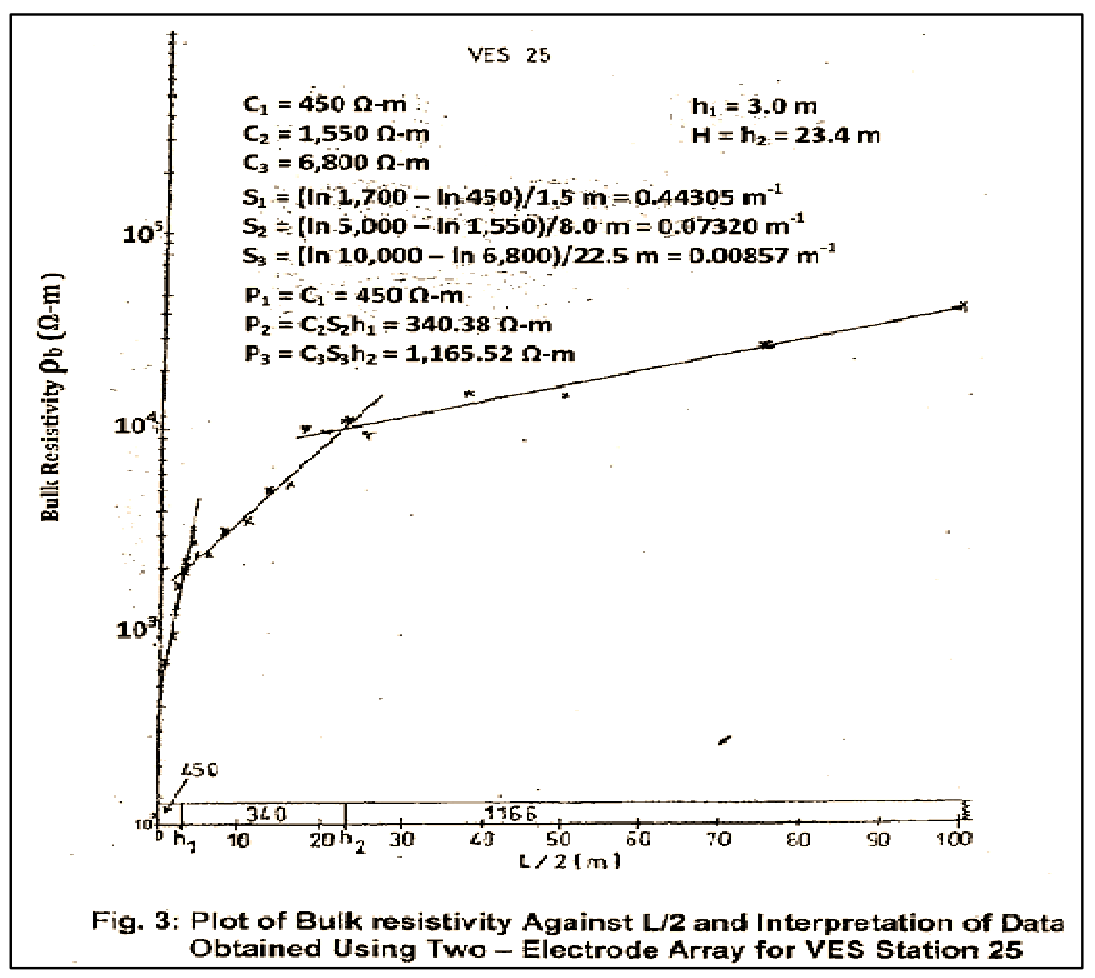

For the Schlumberger array, the field procedure involved the expansion of $A B / 2$ symmetrically about the centre of the spread while keeping the potential electrodes (MN) relatively fixed. The data collected consists of the resistance value read from the Terrameter, the current electrode $A B$ and their corresponding $\mathrm{MN}$ values. The computed "apparent resistivity" values formed the resistivity data for that particular station. Table 2 is a typical reduced data for the Schlumberger array for VES station 25.
The data obtained using the Schlumberger configuration was interpreted by using a computer program (Offix Version 2.0), which performs an iterative curve matching process. The results of the interpretation are in terms of a layered - earth model. A typical example of such an interpretation carried out using the computer program, which shows the curve and model for VES station 25 is given in Fig 4.
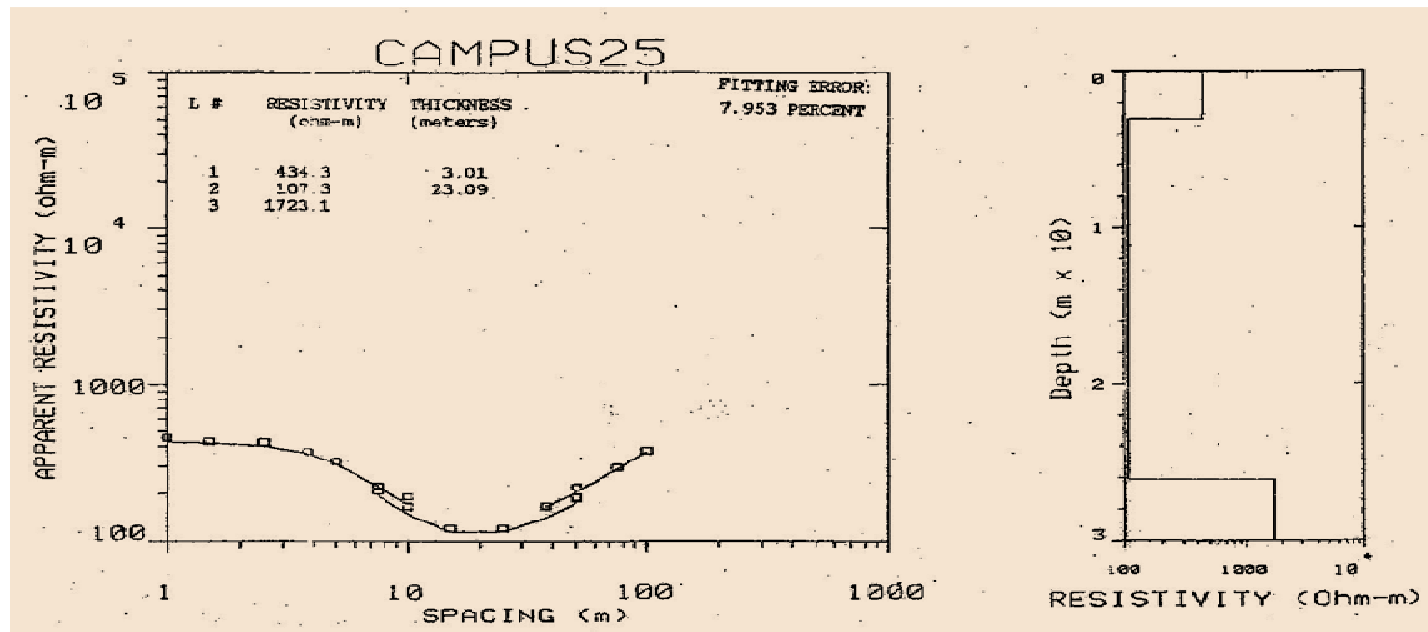

Fig. 4: Interpretation of Apparent Resistivity from the Schlumberger Interpreted Data for VES 25. 


\section{RESULTS AND DISCUSSION}

Figs. 5 and 6 are the depth - to - basement contour maps for the Two-Electrode and Schlumberger arrays respectively
Both contour maps (Figs. 5 and 6) are characterized by closures of low and high depth - to basement values.

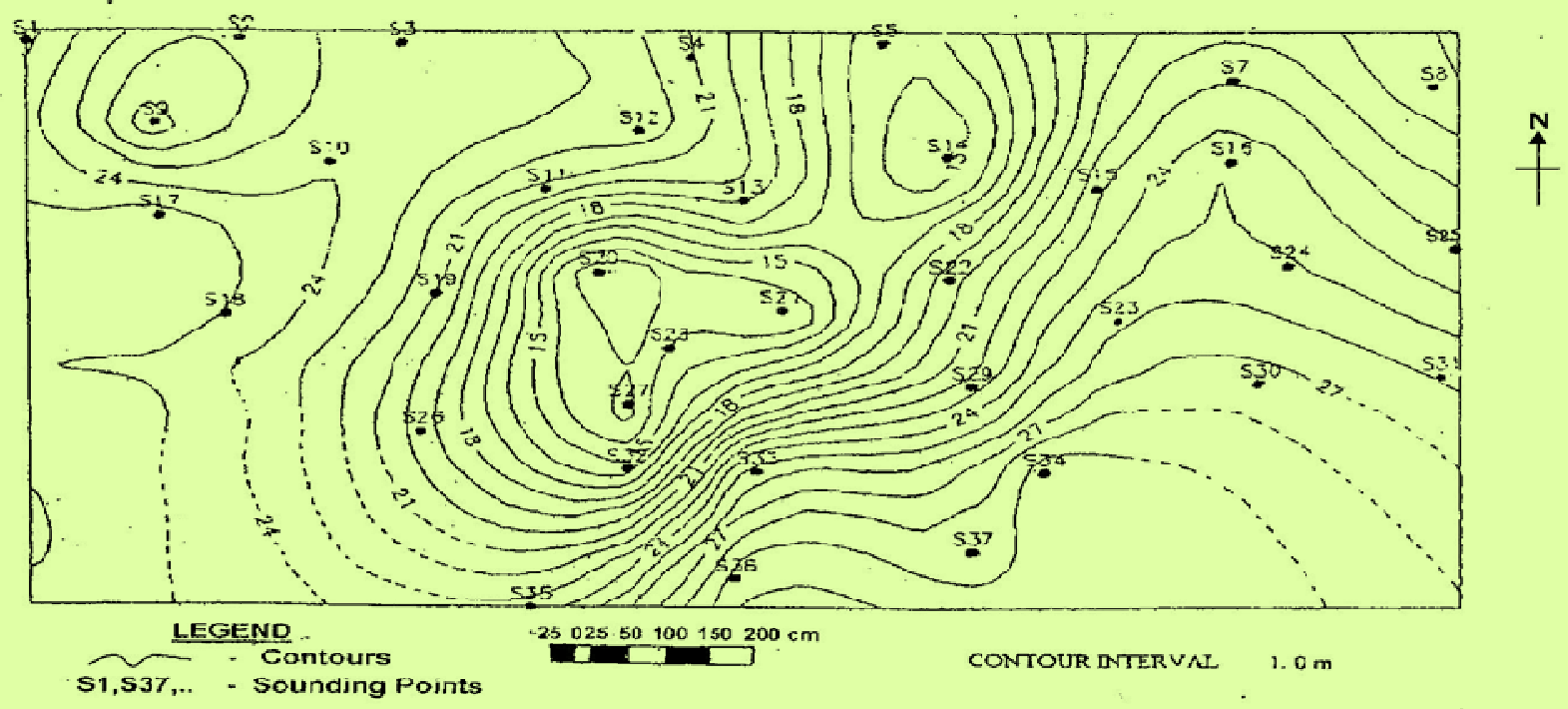

Fig. 5: Depth - to - Basement Contour Map of the Project Area for the Two-Electrode Interpreted Data

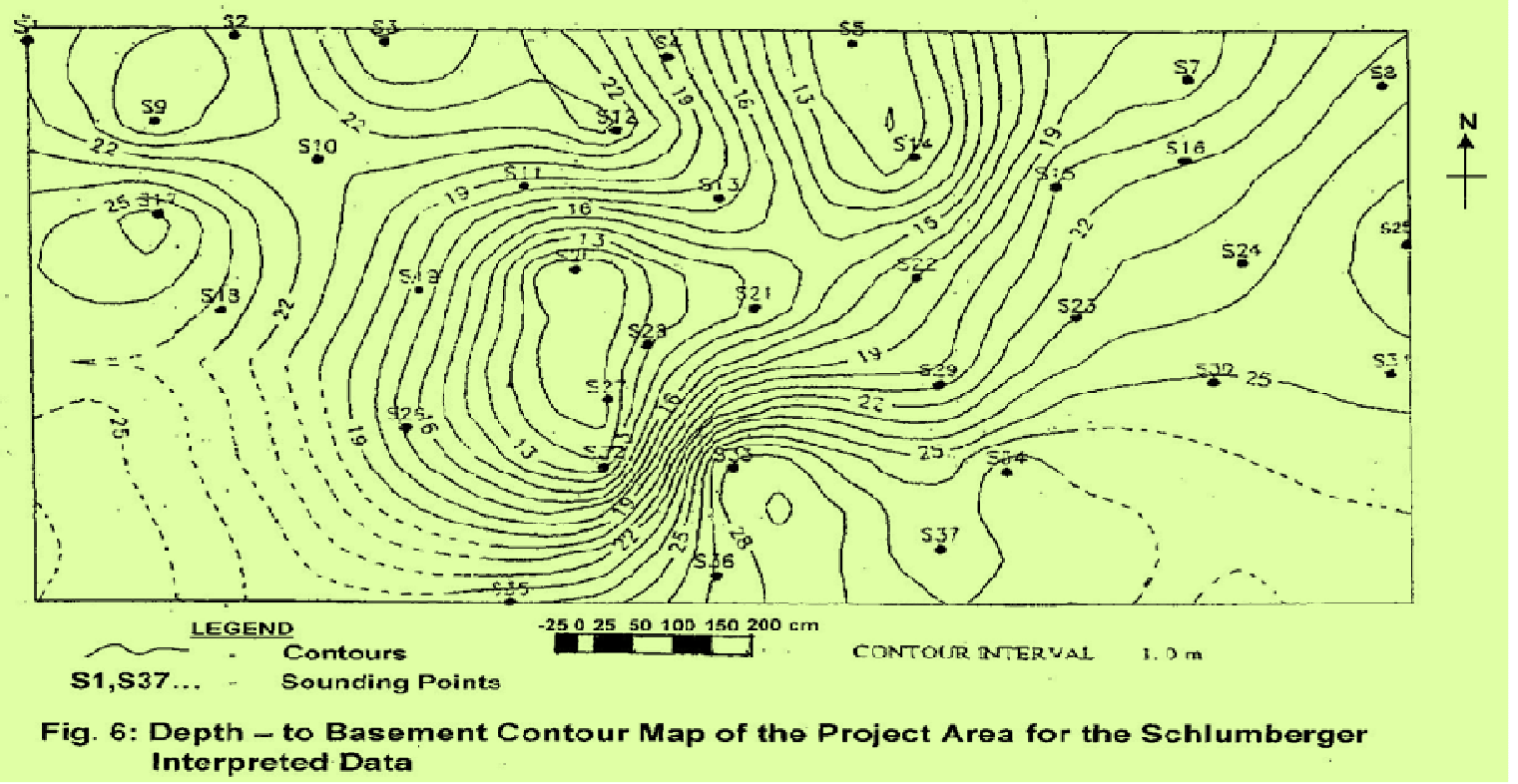

Figs. 7 and 8 are the 3-D cross-section diagrams respectively for the Two - Electrode and Schlumberger arrays.

Geoelectric sections from the interpretation of the two sets of data were drawn along four profiles AA',
BB', CC' and DD' as given in Figs. 9, 10, 11 and 12 respectively.

The undulating nature of the basement underlying the Main Campus is shown in the diagrams. 


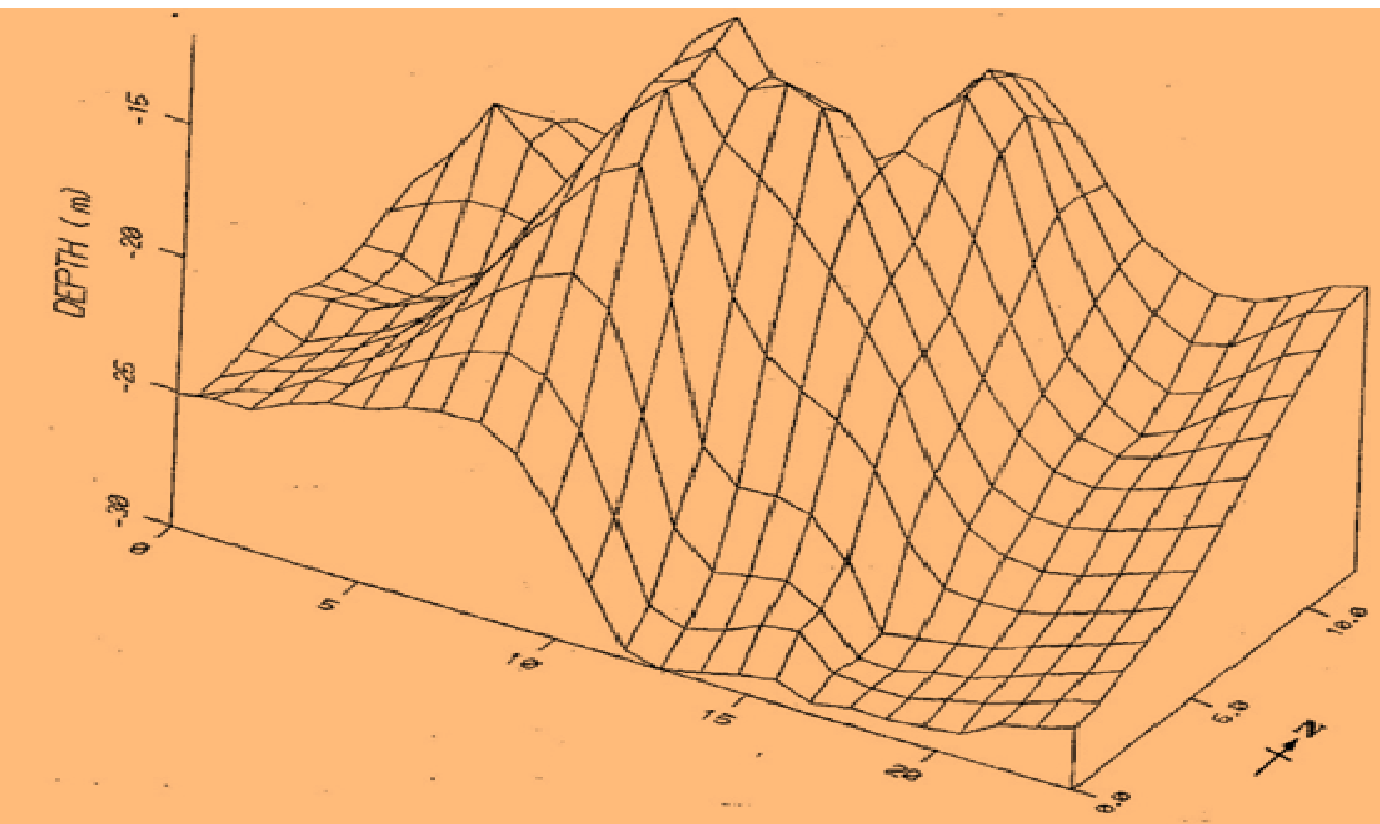
Fig. 7: 3 -D Cross Section View of the Basement Underlying the Project Area from the
Two - Electrode Interpreted Data

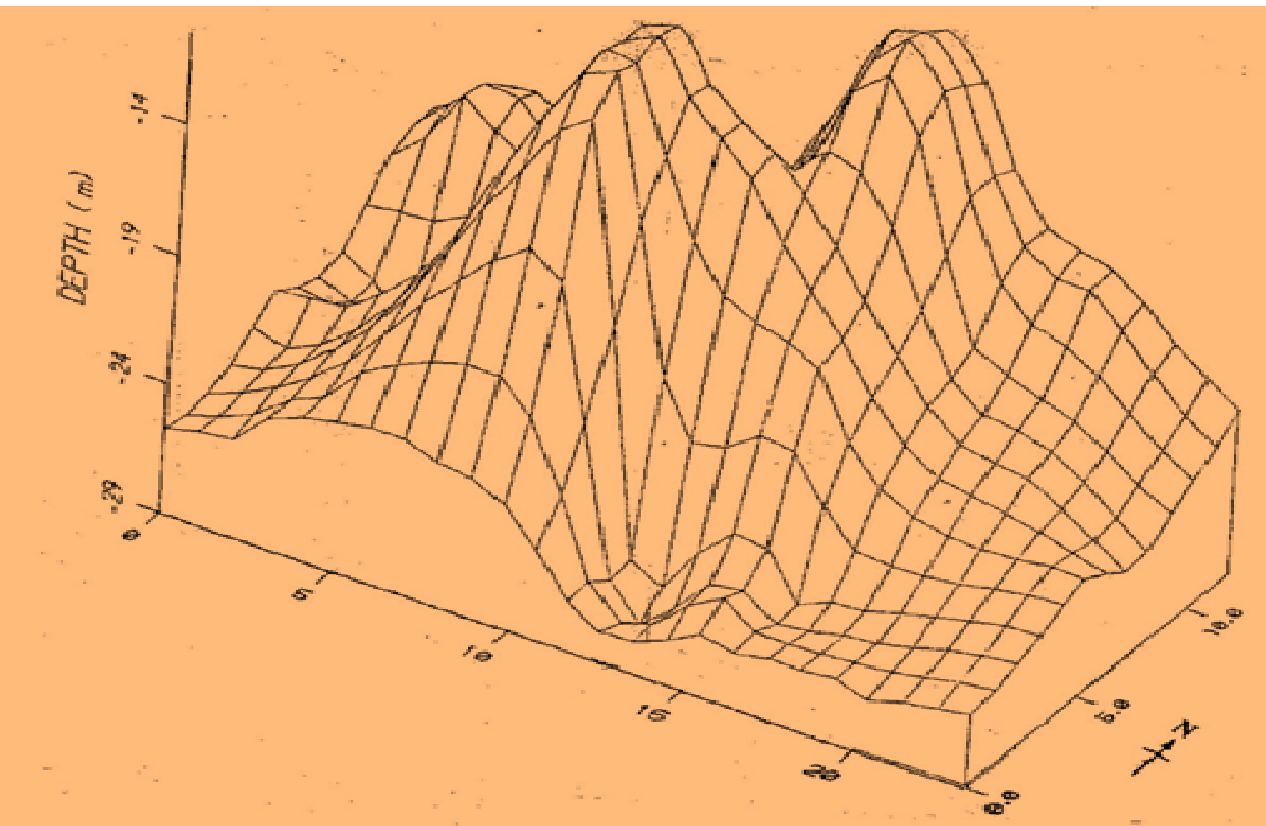

Fig. 8: 3-D Cross Section View of the Basement Underlying the Project Area from the Schlumberger Interpreted Data 


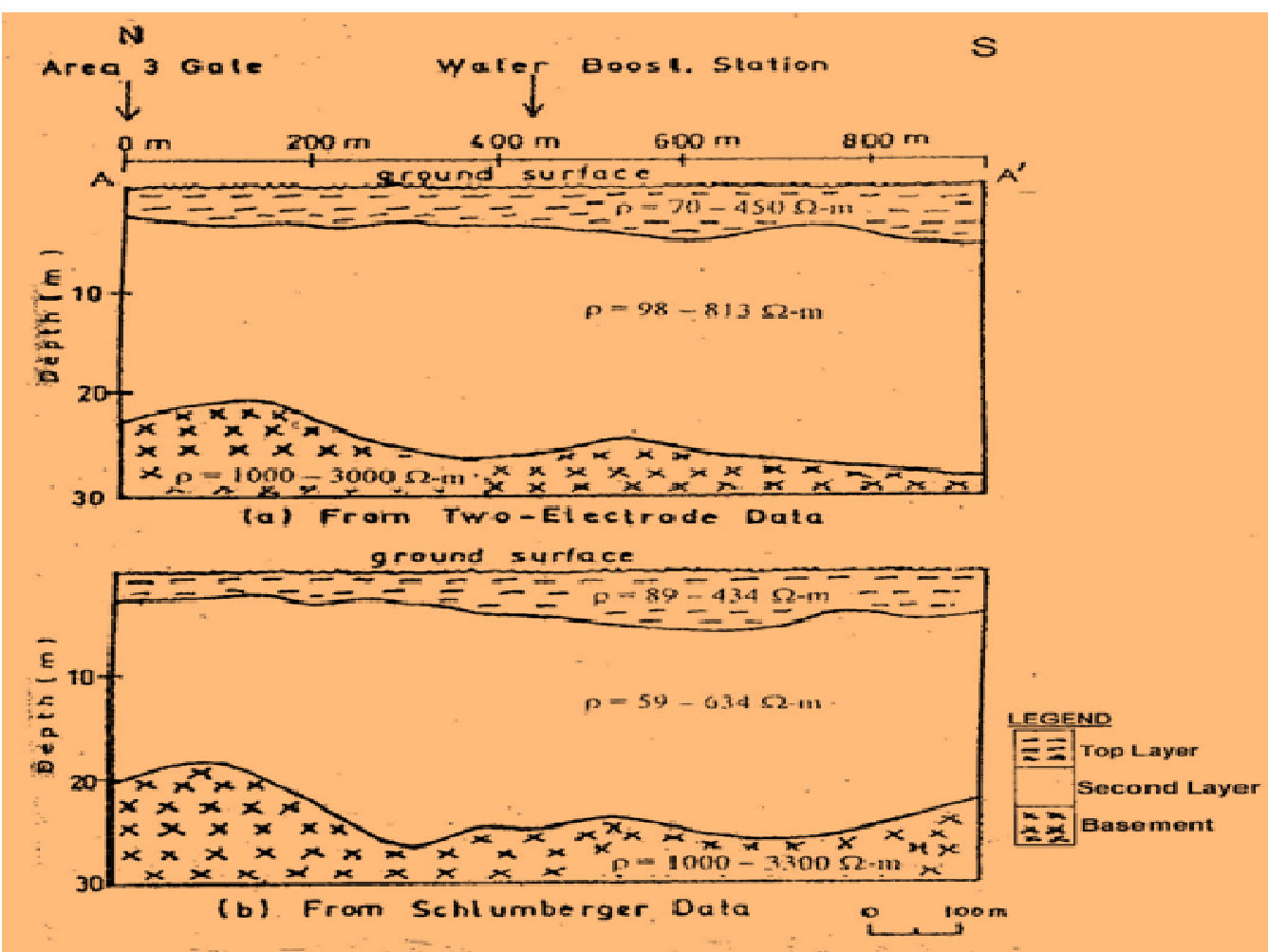

Fig. 9: Geoelectric and Geologic Sections along Profile AA*

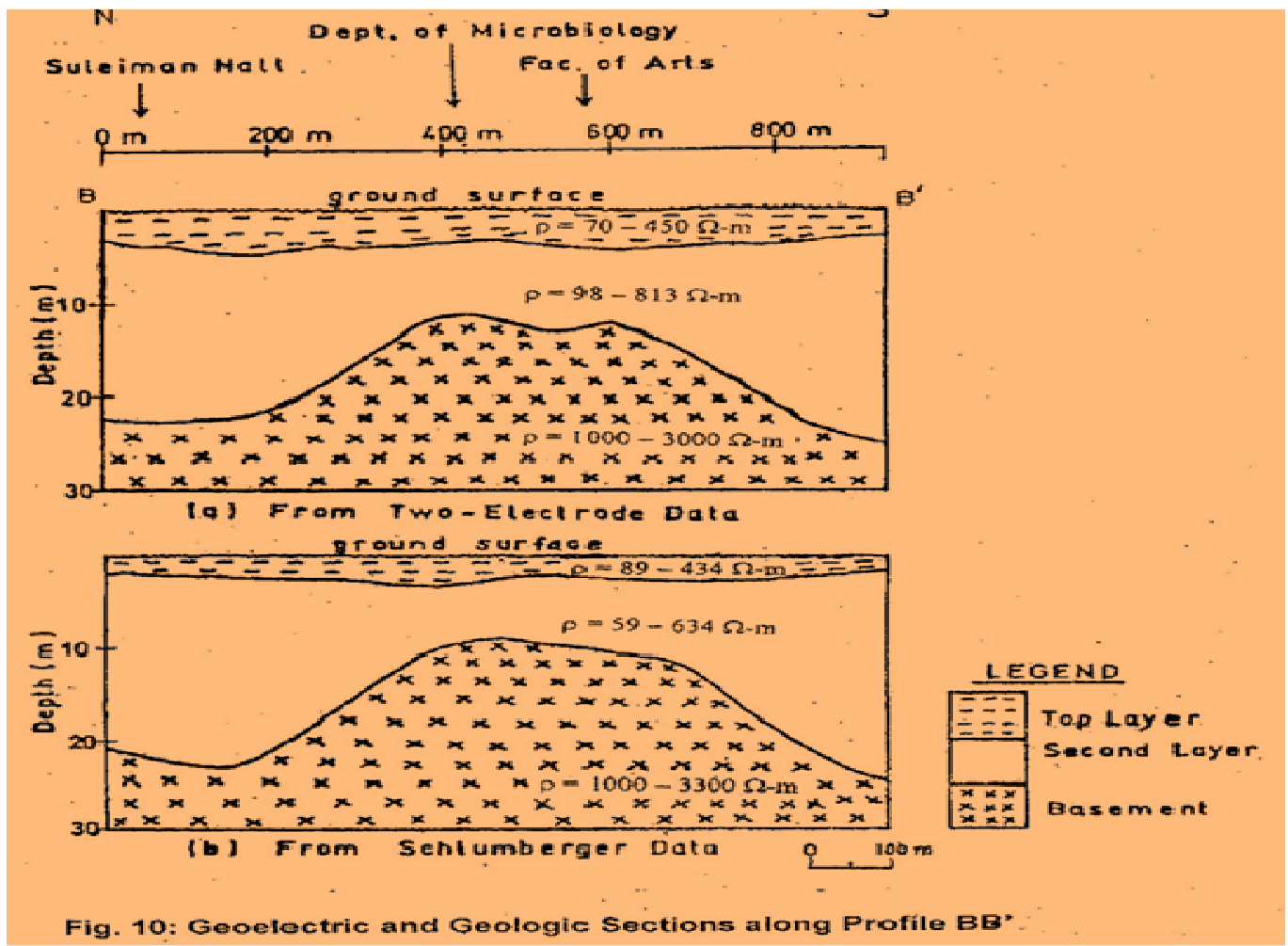




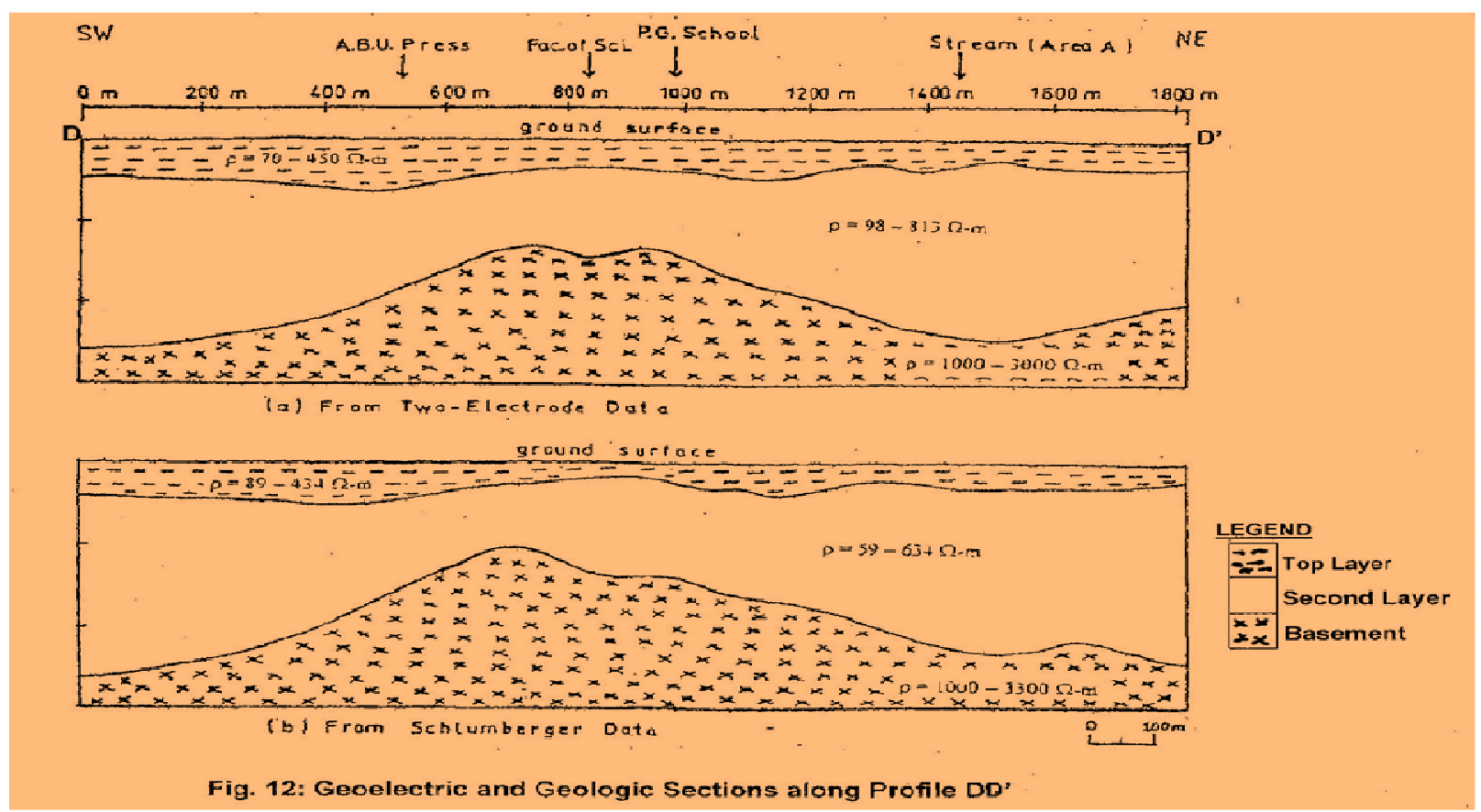

Table 3: Depth - to - Basement Values for the Two Sets of Data

\begin{tabular}{|c|c|c|c|c|c|}
\hline \multirow{2}{*}{$\begin{array}{l}\text { VES } \\
\text { STATION } \\
\text { No. }\end{array}$} & \multicolumn{2}{|c|}{$\begin{array}{l}\text { DEPTH-TO-BASEMENT VALUES } \\
\text { (m) }\end{array}$} & \multirow{2}{*}{$\begin{array}{l}\text { VES } \\
\text { STATIO } \\
\mathbf{N} \\
\text { No. }\end{array}$} & \multicolumn{2}{|c|}{ DEPTH-TO-BASEMENT VALUES (m) } \\
\hline & $\begin{array}{l}\text { TWO- } \\
\text { ELECTRODE } \\
\text { ARRAY }\end{array}$ & $\begin{array}{l}\text { SCHLUMBERGE } \\
\text { R ARRAY }\end{array}$ & & $\begin{array}{l}\text { TWO- } \\
\text { ELECTRODE } \\
\text { ARRAY }\end{array}$ & $\begin{array}{l}\text { SCHLUMBERGE } \\
\text { R ARRAY }\end{array}$ \\
\hline 01 & 25.5 & 22.0 & 20 & 10.5 & 8.3 \\
\hline 02 & 22.0 & 20.0 & 21 & 11.5 & 13.1 \\
\hline 03 & 24.0 & 25.8 & 22 & 20.0 & 18.4 \\
\hline 04 & 21.0 & 18.0 & 23 & 26.0 & 23.1 \\
\hline 05 & 15.0 & 10.1 & 24 & 25.0 & 23.5 \\
\hline 06 & 20.0 & 18.3 & 25 & 23.4 & 26.1 \\
\hline 07 & 23.0 & 19.3 & 26 & 19.5 & 16.7 \\
\hline 08 & 20.0 & 23.7 & 27 & 12.0 & 10.1 \\
\hline 09 & 30.0 & 18.6 & 28 & 15.0 & 13.4 \\
\hline 10 & 24.0 & 21.0 & 29 & 22.0 & 19.9 \\
\hline 11 & 21.0 & 18.4 & 30 & 27.5 & 25.1 \\
\hline 12 & 23.0 & 24.0 & 31 & 26.0 & 24.5 \\
\hline 13 & 20.0 & 17.9 & 32 & 15.0 & 11.7 \\
\hline 14 & 13.0 & 10.5 & 33 & 26.5 & 30.7 \\
\hline 15 & 23.0 & 21.4 & 34 & 30.0 & 25.9 \\
\hline 16 & 25.0 & 22.0 & 35 & 23.5 & 24.3 \\
\hline 17 & 26.0 & 27.0 & 36 & 30.0 & 27.1 \\
\hline 18 & 25.0 & 23.7 & 37 & 28.0 & 26.0 \\
\hline
\end{tabular}

Results of the VES data interpretation of the two-electrode array and Schlumberger array have compared very well as shown in Figs. 5 to 12. The depth - to - basement values obtained from the two sets of interpreted results as given in Table 3 have agreed to about $86 \%$.
The depth - to - basement varies from about $13.0 \mathrm{~m}$ to $30.0 \mathrm{~m}$ for the two-electrode array while that of the Schlumberger array varies from about $11.0 \mathrm{~m}$ to $29.0 \mathrm{~m}$. These values are also within the range of values obtained by previous workers, such as; Ososami (1968), Hassan (1987), Olugbemiro (1985) and Shemang 
(1990) who reported that the depth -to - basement value in the Kubanni Basin varies from less than a metre to about $50.0 \mathrm{~m}$.

A summary of the depth - to - basement values obtained from the interpretation of the two sets of data are given in Table 3.

\section{CONCLUSION}

An attempt was made in this work to determine the effectiveness of the Ajayi - Makinde two - electrode method as a geophysical method of investigation in depth - to - basement determination. The field procedure for the two - electrode array was faster and requires lesser hands as only two electrodes are used.

The interpretation of data for the two - electrode array was simple and straight forward as no computer analysis was involved. Results of the interpretation of the data in this work have also shown that the two electrode array has a greater depth of penetration than the Schlumberger array.

This work has therefore proved that the Ajayi Makinde two - electrode array is reliable and effective in depth - to - basement determinations and can be of use as a geoelectric prospecting method. More research should be carried out for computerized interpretation program and also fabrication of a device for the method.

\section{ACKNOWLEDGEMENT}

Late Prof. C.O. Ajayi is hereby highly acknowledged for his contribution to this work. May his gentle soul rest in perfect peace, Amen.

\section{REFERENCES}

Afolalu F. O., 2009. Two Dimensional Shallow Resistivity Investigation of the Ground Water Potential at Nuhu Bamalli Polytechnic, Zaria Main Campus using Electrical Imaging Technique. The Pacific Journal of Science and Technology 10, (1): 602-613

Ajayi, C. O and Makinde, V., 2000. The "Ajayi-Makinde" Two-Electrode D.C Resistivity Array. A brief Brochure to the Patent Office, Abuja.

Ameloko A. A and Omali A., 2011. Groundwater Exploration with D.C Resistivity Method in Maigamo Area of Kubanni River Basin Zaria, Nigeria. World Rural Observations 3, (1): 72-81.

Ameloko A. A and Rotimi O. J., 2010. 2- D Electrical Imaging and Its Application in Groundwater Exploration in Part Of Kubanni River BasinZaria, Nigeria. World Rural Observations 2, (2): 72-82.

Apparao, A and Roy, A., 1973. Field Results for Direct Current Resistivity Profiling with Two-Electrode Array. Geoexploration, 11, (1): 21-44.

Bajeh, I., 1992. Ground Magnetic Investigation of the
Kubanni River Basin, Zaria. Unpublished M.Sc. Thesis, Ahmadu Bello University, Zaria.

Brizzolari, E and Bernabini, M., 1979. Comparison between Schlumberger Electrode Arrangements and Some Focused Electrode Arrangements in Resistivity Profiles, Geophysical Prospecting, 27, (1): 233-244.

Egwuonwu, G. N and Sule, P. O., 2012. Geophysical Investigation of Foundation Failure of a Leaning Superstructure in Zaria Area, Northern Nigeria. Research Journal in Engineering and Applied Sciences 1, (2): 110-116

Eigbefo, C., 1978. Hydrogeology of the Kubanni Basin, Zaria. Unpublished M.Sc. Thesis, Ahmadu Bello University, Zaria.

Fadele, S. I., Sule, P. O and Dewu, B. B. M., 2013. The Use of Vertical Electrical Sounding (VES) for Groundwater Exploration around Nigerian College of Aviation Technology (NCAT), Zaria, Kaduna State, Nigeria. The Pacific Journal of Science and Technology 14(1), pp 549-555.

Gupta, R. N and Bhattacharya, P. K., 1963. Unipole Method of Electrical Profiling. Geophysics, 28, (4): 608-616.

Hassan, M., 1987. Geoelectrical Investigation of the Western Half of the Kubanni River Basin, Zaria. Unpublished M.Sc. Thesis, Ahmadu Bello University, Zaria.

Jain, S. C and Roy, A., 1973. Comparison of Electrode Arrays in Time Domain Induced Polarization. Geophysical Prospecting, 21, (4): 626-634.

Keller, G. V and Frischknecht, F. C., 1966. Electrical Methods in Geophysical Prospecting. Pergamon Press, New York.

Kumar, R., 1974. Direct Interpretation of Two-Electrode Resistivity Soundings. Geophysical Prospecting, 22, (2): 224-237.

Makinde, V., 1996. A Field Investigation of a Variant of the Two-Electrode D.C. Resistivity Array within the Kubanni Basin. Unpublished Ph.D. Thesis, Ahmadu Bello University, Zaria.

McCurry, P., 1970. Geology of Degree Sheet 21, Zaria. Unpublished M.Sc. Thesis, Ahmadu Bello University, Zaria.

Olowu, J., 1967. Preliminary Investigations of the Groundwater Conditions in Zaria Sheet 102 S. W. GSN Report No. 1462.

Olugbemiro, R. O., 1985. Hydrogeology of Jama'a Kubanni Area (Zaria Sheet 102 S.W.). 
Unpublished B.Sc. Thesis, Ahmadu Bello University, Zaria.

Ososami, I. A., 1968. Assessment of the Groundwater in the Kubanni Valley. Unpublished M.Sc. Thesis, Ahmadu Bello University, Zaria.

Osumeje J. O and Kudamnya E. A., 2014. Hydro geophysical Investigation Using Seismic Refraction Tomography to Study the Groundwater Potential of Ahmadu Bello University Main Campus, within the Basement Complex of Northern Nigeria. Journal of Environment and Earth Science 4, (2): 15-22.

Oyawoye, M. O., 1964. Geology of the Nigerian Basement Complex. Journal of Nigerian Mining, Geological and Metallurgical Society.
Shemang, E. M., 1990. Electrical Depth Sounding at Selected Well Sites within the Kubanni River Basin, Zaria. Unpublished M.Sc. Thesis, Ahmadu Bello University, Zaria.

Thorp M. B., 1970. Land focus and Landscape Evolution of Zaria and its Region. Ed. By M. J. Mortimore. Department of Geography Occasional Paper No. 4. Ahmadu Bello University Zaria.

Trustwell, J. F and Cope, R. N., 1963. The Geology of Parts of Niger and Zaria Provinces. Northern Nigeria GSN Bulletin 29.

Wright, J. B and McCurry, P., 1970. The geology of the Zaria Sheet 102 S.W. and its Region In: Mortimore, M. J. (Ed.). Department of Geography Occasional Paper No. 4. Ahmadu University, Zaria. 